\title{
Does Monetary Policy Stabilize the Exchange Rate Following a Currency Crisis?
}

\author{
ILAN GOLDFAJN and POONAM GUPTA*
}

This paper provides evidence on the relationship between monetary policy and the exchange rate in the aftermath of currency crises. It analyzes a large dataset of currency crises in 80 countries for the period 1980-98. The main question addressed is whether monetary policy can increase the probability of reversing a postcrisis undervaluation through nominal appreciation rather than higher inflation. We find that tight monetary policy facilitates the reversal of currency undervaluation through nominal appreciation. When the economy also faces a banking crisis, the results are not robust and depend on the specification. [JEL E44, E63]

\begin{abstract}
Tight money in a given financial crisis can serve either to attract funds or to repel them, depending on the expectations that a rise in interest rates generates. With inelastic expectations, no fear of crisis or of currency depreciation, an increase in the discount rate attracts funds from abroad, and helps provide the cash needed to ensure liquidity; with elastic expectations of change - of falling prices, bankruptcies, or exchange depreciation-raising the discount rate may suggest to foreigners the need to take more funds out rather than in.
\end{abstract}

-Charles P. Kindleberger (1978)

$n$ the aftermath of currency crises, several economies have seen their exchange rates depreciate beyond what could be justified by fundamentals. Recent examples of this overshooting include Indonesia, Korea, and Thailand during the Asian crisis in 1997 and Brazil in 1999. In this situation, policymakers have to decide whether to tighten policies to stabilize the exchange rate and, in particular, whether higher interest rates are the appropriate response. There is a lively debate in the literature about whether tighter monetary policy is effective in these situations.

\footnotetext{
*Ilan Goldfajn is a Professor at the Catholic University of Rio de Janeiro and a Deputy Governor of Economic Policy at the Central Bank of Brazil. The paper was written when he was an Economist at the International Monetary Fund. Poonam Gupta is an Economist in the IMF's New Delhi office. The authors would like to thank Andrew Berg, Robert Flood, David Goldsbrough, José de Gregorio, Pietro Garibaldi, Paul Masson, Jonathan Ostry, Carmen Reinhart, David Robinson, Mark Stone, Christopher Towe, an anonymous referee, and seminar participants from the Asia and Pacific Department of the IMF, the Central Bank of Chile, the Board of Governors of the Federal Reserve System, George Washington University, Massachusetts Institute of Technology, and the Latin American and Caribbean Economic Association conference held in Buenos Aires in 1998.
} 
Furman and Stiglitz (1998) provide a very comprehensive discussion of the various channels through which high interest rates may affect the exchange rate. ${ }^{1}$

This study attempts to shed light on this debate by analyzing a large set of large depreciations in the aftermath of currency crises in the period 1980 to 1998. The analysis of the effect of tight monetary policy on the exchange rate involves three important steps. The first step is to evaluate whether the exchange rate overshot during the crisis or, in other words, whether the real exchange rate (RER) has become undervalued and needs to be brought back to equilibrium. The second step is to identify the mechanisms through which the RER could be corrected in case it is undervalued.

There are two ways to reverse an undervaluation: through nominal currency appreciation or through higher inflation at home than abroad (or it can be reversed through a combination of the two). If avoiding an inflation buildup is an important concern and/or a nominal appreciation is desirable for the benefit of the domestic corporate sector and banking sector balance sheets, the extent to which the reversals occur through nominal appreciations is fundamental. The third step is to identify the policies and the circumstances under which the reversal occurs through nominal appreciation. In particular, it is important to evaluate whether nominal appreciations occur mainly when interest rates are kept high. In addition, it is also important to evaluate whether other economic conditions-for example, the state of the banking system-influence the relationship between interest rates and exchange rates.

Operationally, the paper selects currency crises that have led to large undervaluations of the real exchange rate and investigates the way the reversals have occurred. It defines as successful cases reversals that occur primarily through nominal appreciations rather than through higher inflation and calculates the probability of successful cases in the overall sample. ${ }^{2}$ The paper calculates the probability that a tight monetary policy-defined as being in effect when, in the aftermath of the crisis, real interest rates are higher than the average real interest rate during the 24 months preceding the crisis-is successful and compares it with the overall probability of success. The traditional approach would suggest that the probability of being successful is higher in cases where a tight monetary policy is implemented. Then, the whole exercise is replicated using only twin crisis cases in which currency crises coincided with banking crises. In principle, one would expect tight monetary policies to be less successful when a country was also experiencing a banking crisis.

The results indicate that tight monetary policy substantially increases the probability of success. For example, for undervaluations greater than 15 percent, the probability of success increases from 27 percent to 44 percent when tight monetary policy is implemented; and for undervaluations greater than 20 percent, the probability of success doubles, increasing from 25 percent to 50 percent. When both currency and banking crises are present, the probability of a successful reversal is not significantly higher.

\footnotetext{
${ }^{1}$ See also Flood and Jeanne (2000), Krugman (1998a and b), Radelet and Sachs (1998), and Stiglitz (1998).

${ }^{2}$ Although it may be interesting to decompose the reversal in the RER to distinguish between home and foreign inflation, this is beyond the scope of the present study.
} 
The exercise carried out in this study differs from previous studies in a few important respects. First, it analyzes the relationship between interest rates and exchange rates in crisis episodes, which are crucial periods for policymakers. This leaves out several interesting issues but allows the study to concentrate on the role of monetary policy in reestablishing currency stability after a large collapse. Previous studies have looked at the general relationship between interest rates and exchange rates, but few studies have concentrated their analysis on crisis episodes. Second, this study examines a large set of currency crises and, therefore, can offer more general results. Previous studies have concentrated on specific currency crisis cases, offering more limited results. ${ }^{3}$ The availability of a sufficient quantity of monthly data from the pooling of countries allows this study to refrain from extracting the relevant information from more "noisy" daily data. Third, the paper studies the relationship between real interest rates and real exchange rates using monthly data as opposed to studying the relationship between the respective nominal variables. In addition, the objective of this study is to evaluate the relationship between tight monetary policy and currency stabilization: both, in our view, are more precisely defined using real rather than nominal variables. Finally, the recent research and availability of data on banking crises allows us to evaluate the relationship between real interest rates and real exchange rates in cases where currency and banking crises occur simultaneously.

One caveat is that since the endogeneity issue is not addressed satisfactorily in the analysis, the results can probably be interpreted as implying correlation rather than causation. A typical endogeneity argument advanced is that interest rates and exchange rates are both driven by the deterioration in investors' confidence during the crisis. The latter increases the risk premium and, consequently, interest rates and, at the same time, depresses the exchange rate. This would, however, typically generate a negative correlation rather than the positive correlation obtained in our study.

The study also does not analyze the role of high interest rates in preventing a currency crisis, since the focus is on the role of interest rates in reversing undervaluation following a currency crisis. ${ }^{4}$ The former issue is analyzed in a contemporary paper by Kraay (1998). Interestingly, Kraay finds no evidence that "(a) interest rates set by the monetary authority systematically increase during speculative attacks that do not culminate in the devaluation of the currency, or (b) increases in these interest rates lower the probability that a speculative attack culminates in the devaluation of the currency." 5

In order to take into account the costs involved in raising interest rates and weigh them against the benefits, the study looks at the effect of tight monetary policy on output growth, inflation, the current account, and debt servicing. It finds

\footnotetext{
${ }^{3}$ For example, the Asian crises and the debate on the role of monetary policy have motivated a few studies to analyze the relationship between exchange rates and interest rates in the five or six most affected countries. See Ghosh and Phillips (1998), Baig and Goldfajn (2002), and Kaminsky and Schmukler (1998).

${ }^{4}$ Though interesting, this issue is beyond the scope of our study.

${ }^{5}$ Kraay's paper, however, uses central bank discount rates to measure the tightness of monetary policy. It is well known that discount rates tend to remain flat and often do not reflect short-run monetary policies. (For example, Sweden's famous 500 percent interest rate defense in September 1992 was not reflected in the discount rate, which remained constant.)
} 
that the recovery of output is steeper, inflation declines more sharply, and the current account improves when monetary policy is tight than when it is not.

This study is organized as follows. Section I explains the methodology and the data used. Section II characterizes the undervaluation cases by looking at their duration and frequency. Section III characterizes the reversals and evaluates the effect of monetary policy, providing the essential results in the paper. Section IV analyzes the behavior of important macroeconomic variables in currency crises, with and without tight monetary policy. Section V presents the econometric analysis, and Section VI concludes.

\section{Methodology and Data}

This paper analyzes all the episodes of currency collapses that resulted in large undervaluations from a sample of 80 countries between January 1980 and January 1998 and studies the role of tight monetary policy in reversing undervaluations through nominal appreciation of the currencies rather than through higher inflation. This exercise requires the definition of four different objects. First, one needs to define the term "undervaluation" and specify the threshold that defines a "large" undervaluation. Second, one needs to define what constitutes a successful reversal-that is, it requires a threshold for the proportion of the reversal to equilibrium that is due to nominal appreciation of the currency. (For example, is a reversal that is 50 percent driven by nominal exchange appreciation a successful case?) Third, one needs to define tight monetary policy and, finally, to specify how to evaluate whether tight monetary policy has helped stabilize the exchange rate.

\section{Definition of Undervaluation}

This study defines undervaluation episodes as departures of the actual real exchange rate from an estimated equilibrium real exchange rate. Specifically, undervaluations are defined as deviations of the actual exchange rate from a Hodrick-Prescott filtered series. The filtered series captures stochastic trends in the series and allows us to concentrate on the cyclical behavior of potentially nonstationary RER series. It represents the predicted equilibrium RER and captures the permanent changes in relative prices between countries, while the estimated undervaluation series represents the cyclical component of the RER movement since, as a misalignment, it must eventually correct itself. This approach will also net out from the undervaluation measure trends in the equilibrium RER, such as the Balassa-Samuelson effect. ${ }^{6}$

The study also defines the equilibrium real exchange rate as the predicted value of the cointegrating regression between the actual real exchange rate and a set of fundamentals, including the terms of trade, openness, government size, and international interest rate, and calculates the undervaluations as deviations from

\footnotetext{
${ }^{6}$ The Balassa-Samuelson effect occurs when a country's productivity in the tradable sector grows faster than those of its trading partners and this differential growth is smaller in the nontradable sector. Then the (cross-country) relative price of nontradables increases and, therefore, the RER appreciates over time.
} 
this equilibrium value (see Goldfajn and Valdés, 1998). In the study, we will use RER series to test for robustness of the results.

Figure 1 presents the definition of an undervaluation episode and its phases. We define the start of an undervaluation case as the time when the difference between the actual RER and our estimate of the steady-state RER is equal to or higher than a certain threshold (for example, 15 percent or 25 percent). The undervaluation ends when this difference hits a second threshold associated with the existence of no undervaluation. We define this second threshold as 5 percent. In order to control for data blips, an episode has to be sustained for more than two consecutive months.

We define four notable points: (i) start, when the undervaluation hits the threshold; (ii) end, when the undervaluation disappears - that is, the RER hits the 5 percent benchmark; (iii) peak, when the undervaluation is the highest; and (iv) history, when the undervaluation first reaches 5 percent. An undervaluation episode is then defined as the start-end period. There are also two phases: historypeak, representing the buildup of the overshooting, and peak-end, representing the reversal to a "normal" level.

\section{Definition of Successful Reversals}

There are two ways to reverse an undervaluation: through nominal currency appreciation or through higher inflation at home than abroad (or a combination of the two). If avoiding an inflation buildup is an important concern and/or nominal appreciation is desirable for the benefit of domestic corporate balance sheets, the extent to which the reversals occur through nominal appreciations is of fundamental importance.

In order to decompose the real appreciation that occurs during the return to equilibrium, we calculate the total appreciation of the actual real exchange rate during the peak-end phase and the total nominal appreciation during that same period. Successful reversals can then be defined as episodes that return to equilibrium with higher than a specified threshold of nominal appreciation of the currency.

Letting $\Delta$ denote percentage change, we have the identity:

$$
\Delta R E R \equiv \Delta E+\Delta\left(P-P^{*}\right)
$$

where $E$ and $R E R$ are the nominal and real effective exchange rate indices, respectively, and $P$ and $P^{*}$ the price indices at home and abroad, respectively. We can then calculate

$$
S=\Delta E / \triangle R E R
$$

as our success index. As a starting point, we define a successful case as occurring when the success index $S$ is greater than 50 percent. We also test the sensitivity of our results to different thresholds for $S$.

\section{Definition of Tight Monetary Policy}

Ideally, one would like to have exogenous shocks to monetary policy in all the crisis episodes. Clearly, there are no such data available. This study identifies a country as experiencing a tight monetary policy when the average real interest rate during 
Figure 1. Definition of Cases and Phases

\section{Real Exchange Rate}

\section{Actual RER}

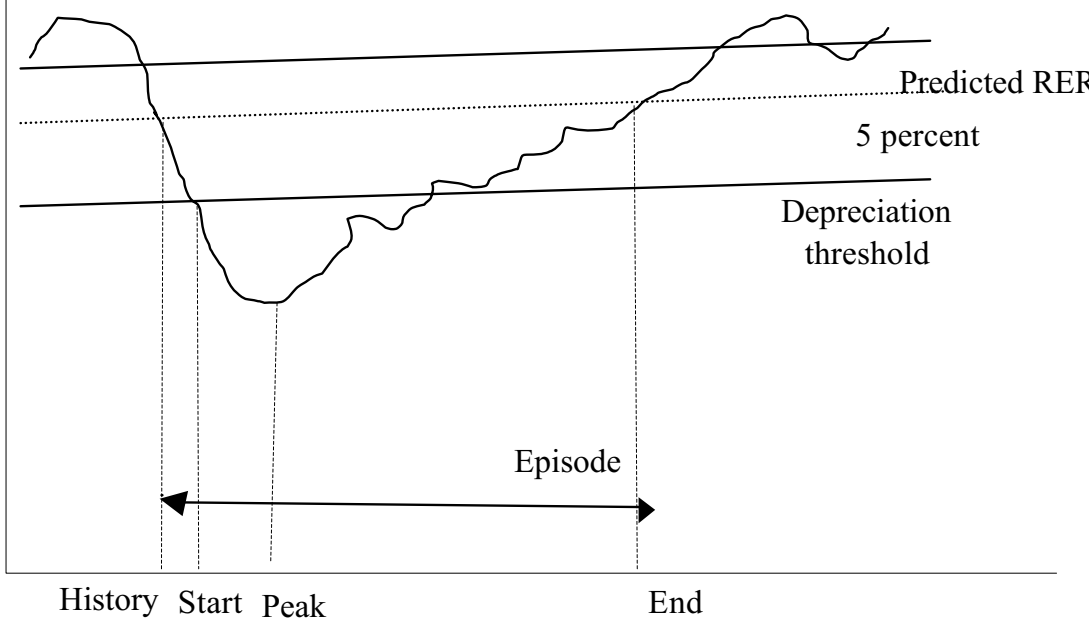

Time

the period of undervaluation, $r$, exceeds a threshold real interest rate. The latter is calculated as the average real interest rate during the 24 months preceding the crises, $\mu_{r}$, plus $x$ times the standard deviation of the series, $\sigma_{r}$ - that is,

$$
r>\mu_{r}+x \sigma_{r} .
$$

As a starting point, we have set $x$ equal to zero in the benchmark case but perform sensitivity analysis.

There are several possible ways to calculate real interest rates, depending on how expected inflation is proxied.7 In this study, we calculate expected inflation by taking the following month's inflation. The real interest rate in period $t$ is then calculated by taking the quarterly moving average of real interest rates, centered at $t$.

The study evaluates the results under different definitions of the real interest rate and tightness definitions.

\section{How to Determine Whether Tight Monetary Policy Has Been Effective}

The study defines monetary policy as having been effective if the conditional probability of reversing an undervaluation through nominal appreciations using tight monetary policy is significantly higher than the unconditional probability

\footnotetext{
${ }^{7}$ See Baig and Goldfajn (1999).
} 
(or higher than the probability of reversing the undervaluation by not using tight policy). In other words, we consider that monetary policy has been effective if in instances where countries had tight monetary policies, we observe a significantly larger proportion of success in reversing an undervaluation than that observed in the overall sample.

The main tables in the study compare the conditional probabilities of success under tight or non-tight monetary policies for different thresholds and definitions. In particular, we will evaluate the probability of success of tight monetary policy with and without a banking crisis.

\section{Data Description}

Our sample consists of monthly data for 80 countries. (See Appendix I for a list of the countries in the sample during the period January 1980 to January 1998.8) The monthly data on nominal interest rates were obtained from the IMF's International Financial Statistics (IFS). For nominal interest rates, we used the series for money market rates and treasury bill rates. In a few cases where none of the above-mentioned series were available, the series for deposit rates or discount rates was used.

The data on seasonally adjusted consumer price indices (CPIs), nominal effective exchange rates, and real effective exchange rates were obtained from the IMF's Information Notice System (INS). ${ }^{9}$ The use of the INS effective real exchange rate should, in principle, consider the effect of competitive devaluations in third markets. The existence of banking crises is summarized by a dummy series. The dates of banking crises have been obtained from Lindgren, Garcia, and Saal (1996); Caprio and Klingebiel (1996); and Demirgüç-Kunt and Detragiache (1998). Since these studies provide only annual data, monthly data were interpolated by assuming that the crisis lasted from January of the year in which it started until December of the year in which it ended.

\section{Characterizing Undervaluation During Crises}

In this section, we present several characteristics of the undervaluation episodes in our sample. In particular, we analyze the number of episodes with different magnitudes of undervaluation, the average duration of the undervaluation episodes, the proportion of cases in which banking problems were also experienced (that is, of twin-crises cases), and the proportion of cases in which monetary policy was tight.

\section{Number of Cases}

The number of episodes clearly depends on the cutoff that defines undervaluation. We identified 77 cases of undervaluation using a 15 percent cutoff - that is, there are 77 cases in our sample where the real exchange rate has overshot by at least

\footnotetext{
${ }^{8}$ We started with the same set of 93 countries as included in Goldfajn and Valdés (1998); because of the unavailability of the data, however, some countries had to be dropped, and the final sample consisted of 80 countries.

${ }^{9}$ The nominal and real exchange rates have been defined such that an increase is an appreciation.
} 


\begin{tabular}{|c|c|c|c|}
\hline $\begin{array}{l}\text { Undervaluation }{ }^{1} \\
\text { (percent) }\end{array}$ & $\begin{array}{l}\text { Number } \\
\text { of Crises }\end{array}$ & $\begin{array}{l}\text { Proportion } \\
\text { of Cases with } \\
\text { Tight Policy }{ }^{2}\end{array}$ & $\begin{array}{l}\text { Proportion } \\
\text { of Cases with } \\
\text { Banking Crises }{ }^{3}\end{array}$ \\
\hline 15 & 77 & 23.4 & 45.5 \\
\hline 20 & 57 & 24.6 & 47.4 \\
\hline 25 & 47 & 23.4 & 44.7 \\
\hline 30 & 36 & 19.4 & 47.2 \\
\hline 35 & 22 & 9.1 & 36.4 \\
\hline \multicolumn{4}{|c|}{$\begin{array}{l}\text { Source: Authors' calculations. } \\
{ }^{1} \text { Misalignment with respect to constructed real exchange rate equilibrium. } \\
{ }^{2} \text { Tight policy is defined as a real interest rate larger than the average for the previous } 24 \text { months } \\
{ }^{3} \text { Banking crises dummy as in Lindgren, Garcia, and Saal (1996). }\end{array}$} \\
\hline
\end{tabular}

15 percent. As we make the definition stricter by raising the cutoff, the number of undervaluation cases declines. Thus, while the number of cases with more than a 20 percent undervaluation declines to 57, there are just 36 cases in which the real exchange rate is found to be undervalued by more than 30 percent. These results are presented in Table 1.

Table 1 also shows the proportion of banking crises in the sample. We identified about 36-45 percent of the undervaluation cases to be twin-crises cases-that is, we have found that about one-third to nearly one-half of the undervaluation cases are accompanied by a fragile banking sector. ${ }^{10}$ This confirms previous results in the literature that find strong evidence for the simultaneous occurrence of banking and currency crises.

We find monetary policy to be tight in nearly one-quarter of the cases with more than 10 percent undervaluation. The percentage of such cases declines when the threshold used to define undervaluation is increased.

\section{Duration of Undervaluations}

We also examined the average duration for which the real exchange rate remained undervalued after a currency crisis. The average duration of the undervaluation was found to be about 27 months for the cases with more than a 15 percent undervaluation. The average buildup phase-that is, the history-peak phase-is 7.2 months, which is considerably shorter than the phase of reversal-that is, the peak-end phase-about 20 months. These results are summarized in Table 2. We compare the duration of cases with tight and non-tight monetary policies and find that the former cases are more prolonged.

We also present a frequency histogram of the duration of the buildup phase and the reversal phase in Figure 2. As can be seen from the figure, there is a great asymmetry in the duration of these two phases. On the one hand, in more than 65 percent

\footnotetext{
${ }^{10}$ See Kaminsky and Reinhart (1999) for evidence on the existence of twin crises and various explanations of why such crises may arise.
} 


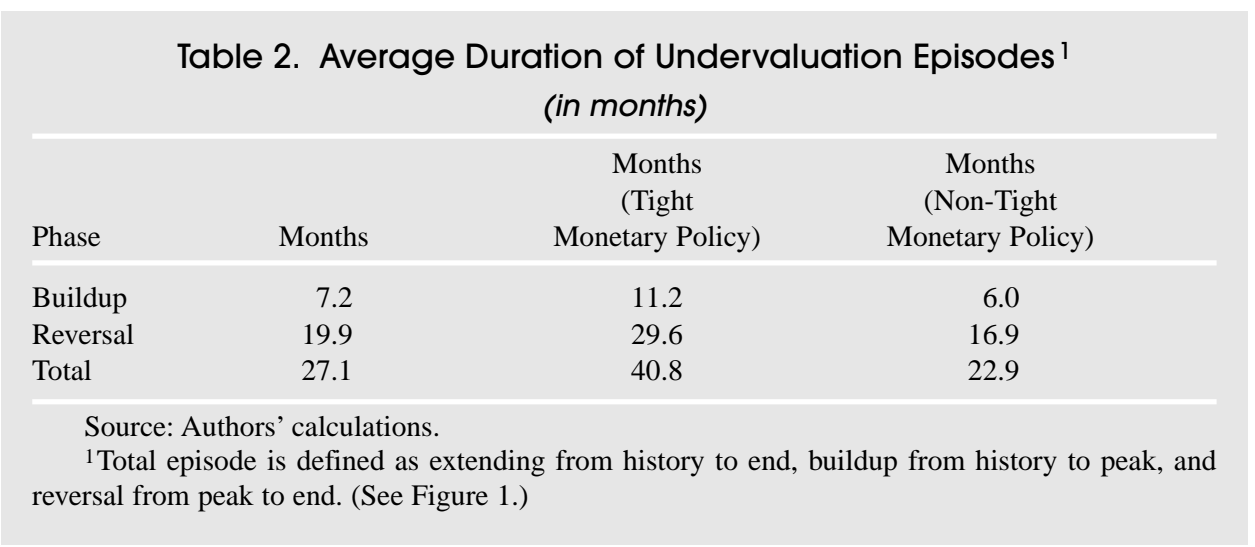

of the cases the buildup takes only one to three months, and in almost 80 percent of the cases it takes less than one year. On the other hand, the reversal takes much longer: in only 30 percent of the cases does reversal take less than one year.

\section{Characterizing Reversals and the Effect of Monetary Policy}

In this section, we address the main questions raised in this paper. What is the probability that a reversal occurs through nominal appreciation rather than through higher inflation? What is the effect of a tight monetary policy on the probability of successful reversals? Does the condition of the banking system alter the effectiveness of monetary policy?

We first analyze the proportion of successful cases. Then we identify the proportion of successes in cases where interest rates were kept high. In light of the recent debate on how the state of the banking system may influence the relationship between interest and exchange rates, we analyze the effect of the health of the banking sector on the probability of a successful reversal.

\section{Unconditional Reversals: Proportion of Nominal Appreciation Versus Inflationary Returns}

In Figure 3 we present the probability of reversal through nominal appreciation for varying degrees of undervaluation. We define successful cases as the ones in which nominal appreciation of the exchange rate is responsible for at least 50 percent of the reversal in the real exchange rate. We found that in a significant number of cases, the reversal comes through a nominal appreciation of the currency-for example, 31 percent of the undervaluation cases of more than 15 percent were found to be successes. The percentage of successful cases declines, but not significantly, for undervaluations of higher magnitudes. Thus, about 25 percent of the undervaluations of greater than 30 percent were reversed through nominal appreciations. This implies that the magnitude of the overshooting does not significantly affect the probability of reversing the undervaluation through nominal appreciations. 
Figure 2. Phases Duration Histogram

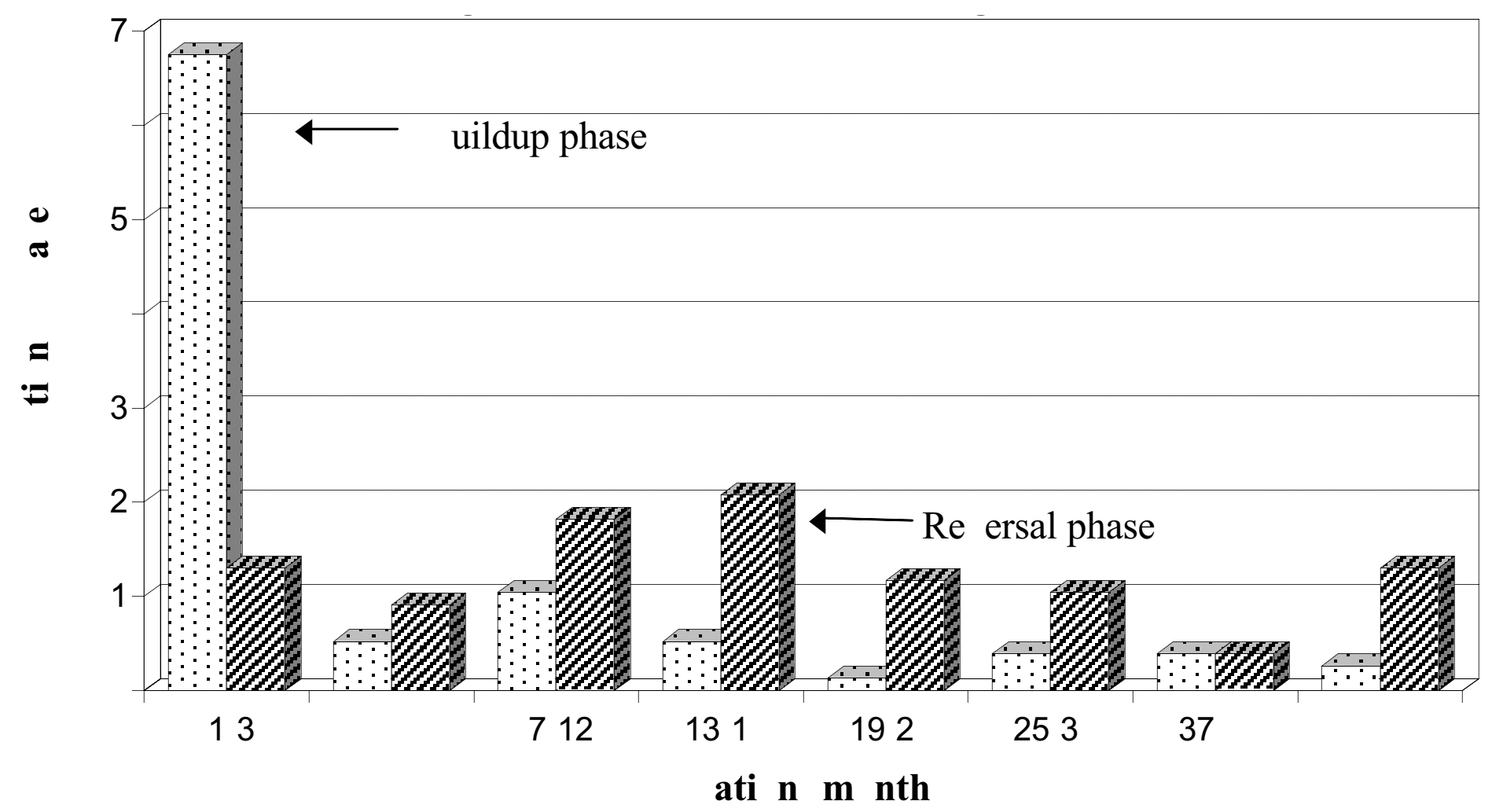




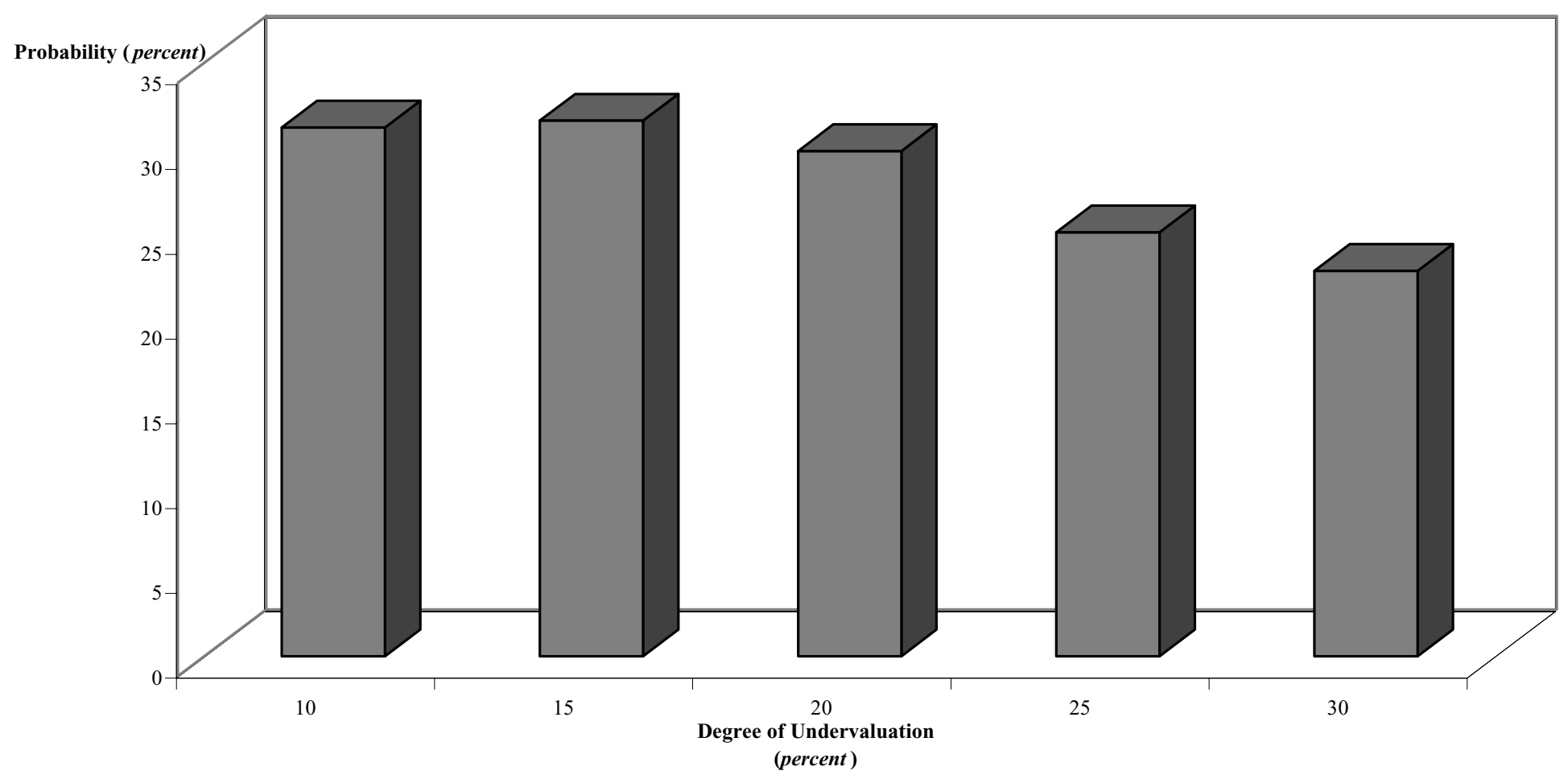




\section{Table 3. Unconditional Probabilities Versus Conditional Probabilities of Success

\begin{tabular}{|c|c|c|c|c|}
\hline $\begin{array}{l}\text { Undervaluation }{ }^{1} \\
\text { (percent) }\end{array}$ & $\begin{array}{l}\text { Unconditional } \\
\text { Probability }\end{array}$ & $\begin{array}{l}\text { Probability } \\
\text { Conditional on } \\
\text { Tight Policy }\end{array}$ & $\begin{array}{l}\text { Probability } \\
\text { Conditional on } \\
\text { Non-Tight } \\
\text { Policy }\end{array}$ & $\begin{array}{c}\text { Significance } \\
\text { Test }^{2}\end{array}$ \\
\hline 15 & 0.31 & 0.44 & 0.27 & \\
\hline 20 & 0.32 & 0.50 & 0.26 & $*$ \\
\hline 25 & 0.30 & 0.55 & 0.22 & $*$ \\
\hline 30 & 0.25 & 0.57 & 0.17 & $*$ \\
\hline 35 & 0.23 & 1.00 & 0.15 & $*$ \\
\hline
\end{tabular}

\section{Conditional Reversals: Proportion of Successful Cases with Tight Monetary Policy}

Table 3 and Figure 4 address one of the main questions of the paper, which is what effect tight monetary policy has on bringing the reversal through nominal appreciation. The probability of success conditional on using tight monetary policy is substantially higher than the probability of success conditional on non-tight policy. Thus, while the probability of success is only 27 percent for an undervaluation of at least 15 percent for cases with non-tight monetary policy, the probability increases to 44 percent for cases with tight monetary policy. This result is confirmed for all the different degrees of undervaluation. For different thresholds of undervaluations, we find the probability of successful reversals to be significantly higher for tight monetary policy at significance levels of 85 percent or higher. The test statistic used is chi-square. (See Appendix II for details.)

Thus, the results could lend support to the use of tight monetary policy to correct an undervaluation of the currency. One has to interpret the results with caution, however. Since there is no truly exogenous policy variable in this exercise, the higher incidence of successes under high real interest rates could be due to the effect of a third factor.

Notwithstanding this caveat, the fact that our results show a positive correlation between tight monetary policies and nominal appreciations is interesting. A typical "endogeneity" argument advanced is that interest rates and exchange rates are both driven by the deterioration in investors' confidence during the crisis. The latter increases risk premiums and, consequently, interest rates and, at the same time, depresses the exchange rate. This would typically generate a negative correlation rather than the positive correlation obtained here.

\section{Proportion of Successful Cases with Banking Problems}

A vulnerable banking and corporate sector raises the often-mentioned trade-off between banking sector fragility and exchange rate stability that a policymaker faces when choosing a monetary policy. The policymaker may be less willing to raise the 
(percent)

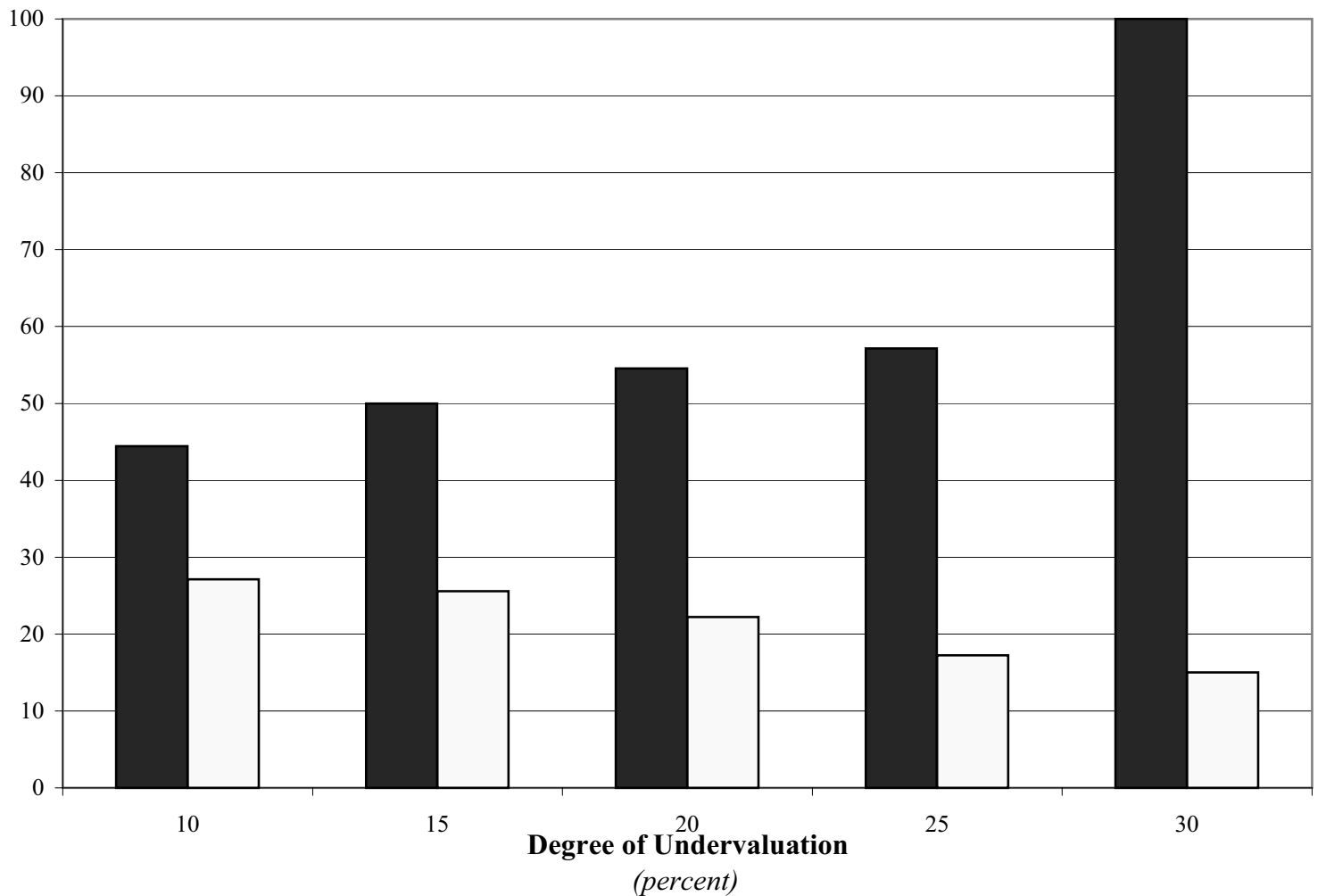

Tight $\square$ Non-Tight

Source: Authors' calculations. 


\section{Table 4. Unconditional Versus Conditional Probabilities of Choosing Tight Policy ${ }^{1}$

$\begin{array}{ccc}\text { Undervaluation } & \text { Unconditional } & \text { Probability Conditional } \\ \text { (percent }) & \text { Probability } & \text { on Banking }\end{array}$

$\begin{array}{lll}15 & 0.23 & 0.23 \\ 20 & 0.25 & 0.26 \\ 25 & 0.23 & 0.24 \\ 30 & 0.19 & 0.18 \\ 35 & 0.09 & 0.13\end{array}$

Source: Authors' calculations.

${ }^{1}$ Success is defined as 50 percent of reversal achieved through nominal appreciation.

interest rate to defend the currency when the banking and/or corporate sectors are exposed to the interest rate increases. ${ }^{11}$ This is compounded by the fact that interest rate increases may affect an investor's expected return. Interest rates may affect the probability of default by increasing the debt-servicing burden of the corporations, by depressing the economy and reducing profits, by altering the net worth of corporations adversely exposed to interest rate changes, or, finally, by affecting the health of the banking system, which naturally tends to be exposed to interest rate changes. ${ }^{12}$

In fact, we find that policymakers choose tight policies approximately as often when they are simultaneously facing a banking crisis. In Table 4, we show that the unconditional probability of choosing a tight monetary policy is similar to the probability of choosing a tight monetary policy conditional on having a banking crisis at different thresholds.

Moreover, when tight monetary policy is adopted, the probability of a successful recovery increases, but not significantly. (See Table 5 and Figure 5.) An important caveat, though, is that for larger thresholds of undervaluation, our data may not be representative, since the number of twin-crises cases with tight monetary policy is very small.

\section{Macroeconomic Variables Under Tight and Non-Tight Monetary Policy}

Even if one accepts that tight monetary policy helps to stabilize the exchange rate, one also needs to take into account the costs involved in raising interest rates and weigh them against the benefits. Therefore, a natural sequence for this study is to look at the effect of tight monetary policy on output growth, inflation, and debt service.

In this section, we analyze the behavior of the growth rate of output, inflation, the current account (as a percentage of GDP), and debt servicing (as a percentage

\footnotetext{
${ }^{11}$ Other factors affecting the choice of monetary policy may include the stock of government debt and the increased burden of debt servicing.

${ }^{12}$ Ideally, one would like to analyze the effects of the health of the banking sector as well as of the corporate sector on the reversal process and on the relationship between the real interest rate and the real exchange rate. Because of the data limitations, however, we analyze just the effect of the health of the banking sector.
} 
Probability of Success

(percent)

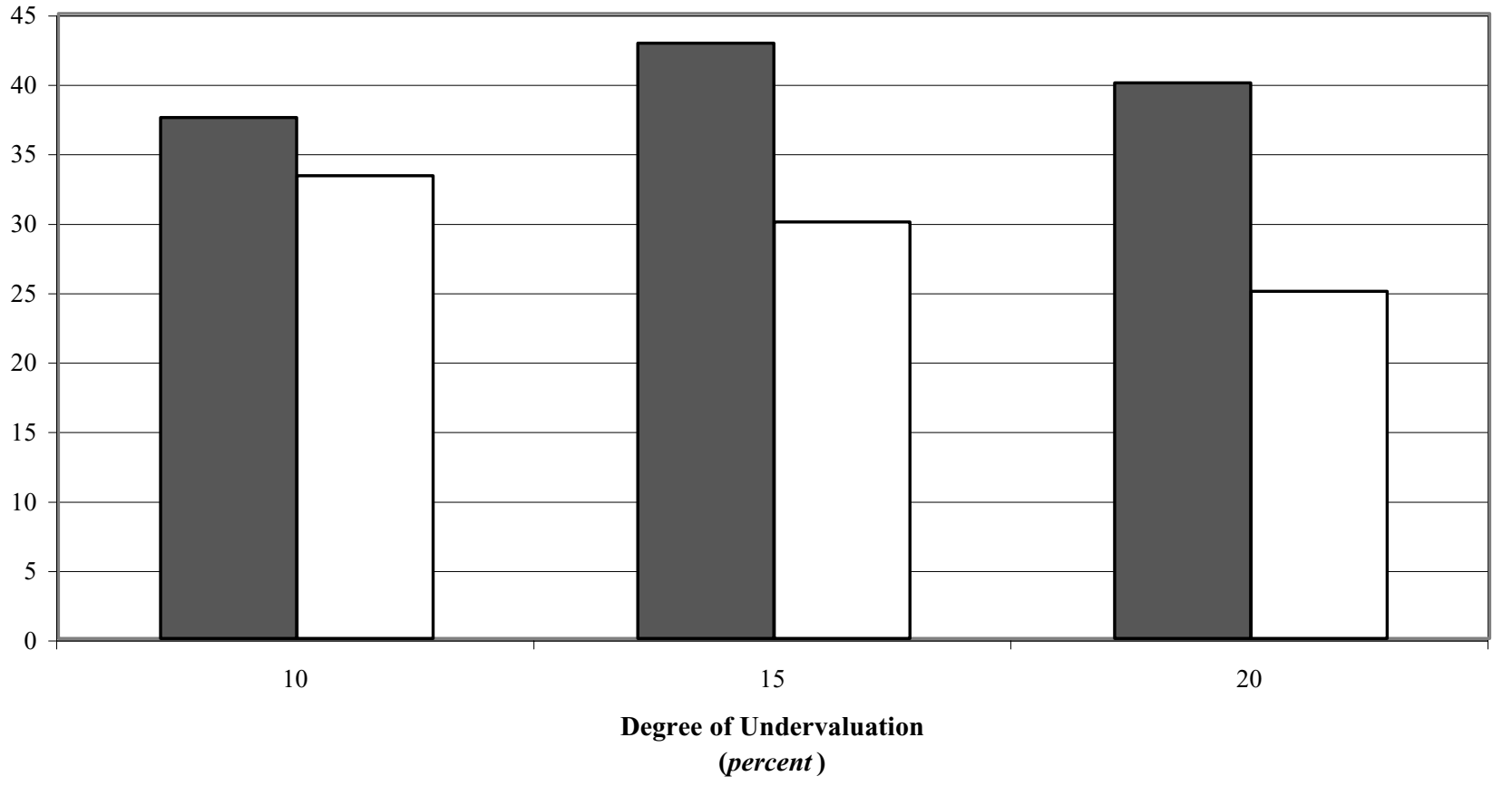

$\square$ Tight $\square$ Non-Tight

Source: Authors' calculations. 


\section{Table 5. Unconditional Probabilities Versus Conditional Probabilities of Success in Twin Crises ${ }^{1}$

\begin{tabular}{|c|c|c|c|c|}
\hline $\begin{array}{l}\text { Undervaluation }{ }^{1} \\
\text { (percent) }\end{array}$ & $\begin{array}{l}\text { Unconditional } \\
\text { Probability }\end{array}$ & $\begin{array}{l}\text { Probability } \\
\text { Conditional on } \\
\text { Tight Policy }\end{array}$ & $\begin{array}{l}\text { Probability } \\
\text { Conditional on } \\
\text { Non-Tight } \\
\text { Policy }\end{array}$ & $\begin{array}{c}\text { Significance } \\
\text { Test }^{2}\end{array}$ \\
\hline 15 & 0.34 & 0.38 & 0.33 & \\
\hline 20 & 0.33 & 0.43 & 0.30 & \\
\hline 25 & 0.29 & 0.40 & 0.25 & \\
\hline 30 & 0.29 & 0.66 & 0.21 & \\
\hline 35 & 0.38 & 1.00 & 0.29 & \\
\hline
\end{tabular}

of GDP) in currency crises under tight and non-tight monetary policies. Given the unavailability of higher-frequency data, this exercise is conducted using annual data. Following the methodology developed in Eichengreen, Rose, and Wyplosz (1994), we first calculate the average value of the variable during the tranquil periods. Tranquil periods include all the years in the sample period, 1980-98, except for the years of undervaluation. Then we take the deviation of the variable from the average value during a few years around the time of undervaluation. A positive value in any of these years indicates that the value of the variable is higher during that year than the average of the tranquil periods. We distinguish between the cases with tight monetary policy (TMP cases) and those with non-tight monetary policy (NTP cases) and compare the behavior of the variables.

For this exercise, data on GDP, the nominal exchange rate, the current account, and inflation were obtained from the IMF's International Financial Statistics database. Data on debt servicing were obtained from the World Bank's Global Development Finance database, which measures the ratio of interest payments on external debt to GNP.

Figures 6-9 depict the behavior of these variables of interest around the crisis period. Each figure shows the behavior of the variable for the whole sample (the broken line) and for the subsamples of tight monetary policy and non-tight monetary policy. In the figures, we focus on the year preceding the undervaluation, $c-1$; the year when it started, $c$; and the subsequent four years, $c+1, \ldots, c+4$.

Figure 6 shows that during the undervaluation periods, inflation starts out higher than the average for the tranquil periods and then declines. Inflation is higher in the tight monetary cases than in the non-tight monetary cases to begin with and then declines more sharply. This is consistent with the result that tight monetary policy is more successful. Figure 7 shows that the current account balance in the tight monetary cases is lower than the average before the undervaluation but improves and becomes higher afterward. Moreover, it is more negative in tight monetary cases before and during the year of the undervaluation but then improves to surpass and stay above the level of non-tight cases. Figure 8 shows that during the periods of undervaluations, the burden of debt servicing is higher than the average. Moreover, 
Deviation from Average (percent)

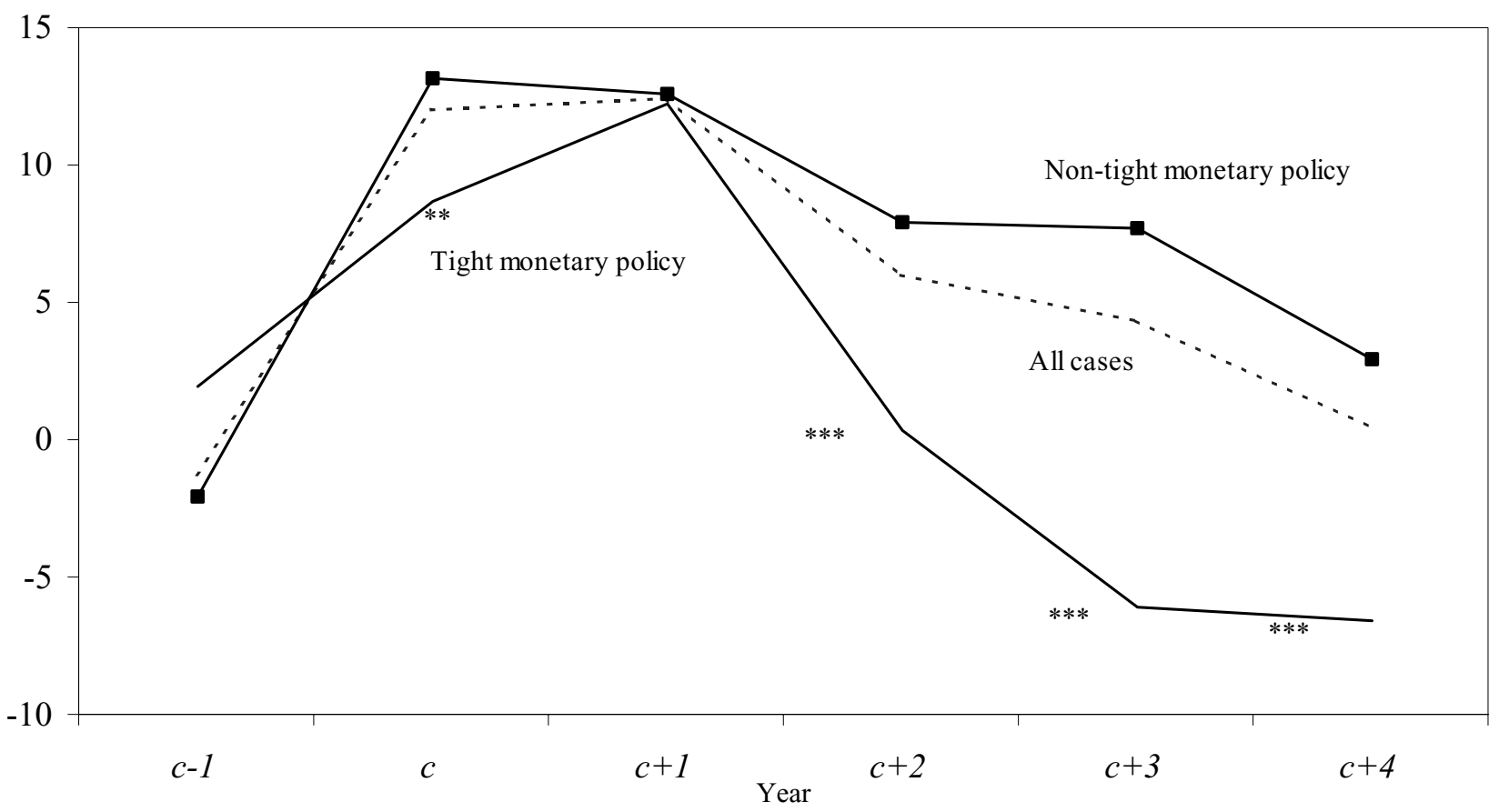

Sources: IMF, International Financial Statistics database; and authors' calculations.

Note: The symbols $* * * * *$, and $*$ denote statistically significant $t$-ratios (for differences in values for tight and non-tight monetary policy) at the 1,5 , and 10 percent levels, respectively. 


\section{Figure 7. Current Account Balance During and After Undervaluation}

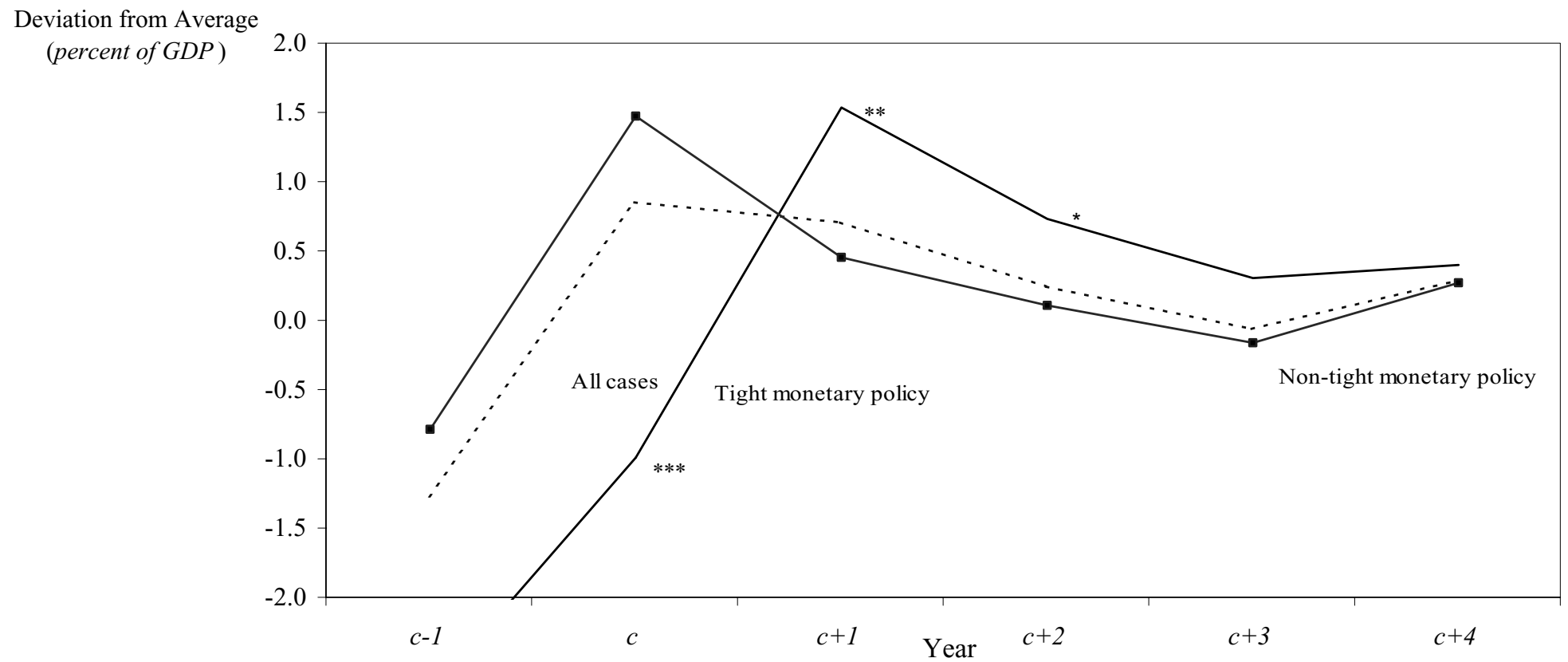


Deviations from Average

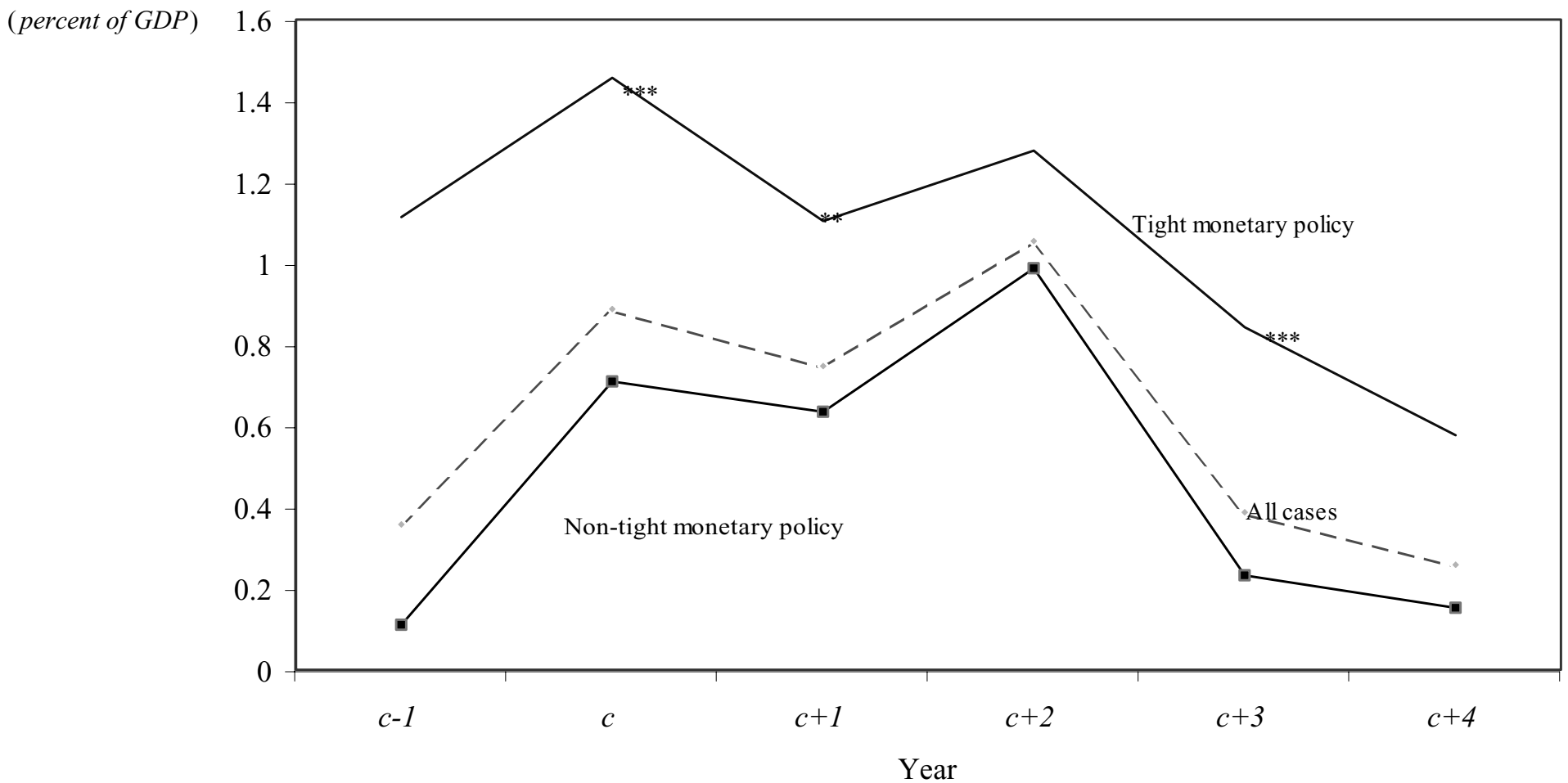

Sources: World Bank, Global Development Finance (Washington), various issues; and authors' calculations.

Note: The symbols $* * *, * *$, and $*$ denote statistically significant $t$-ratios (for differences in values for tight and non-tight monetary policy) at 1,5 , and 10 percent levels respectively. 


\section{Figure 9. Output Growth Rate During and After Undervaluation}

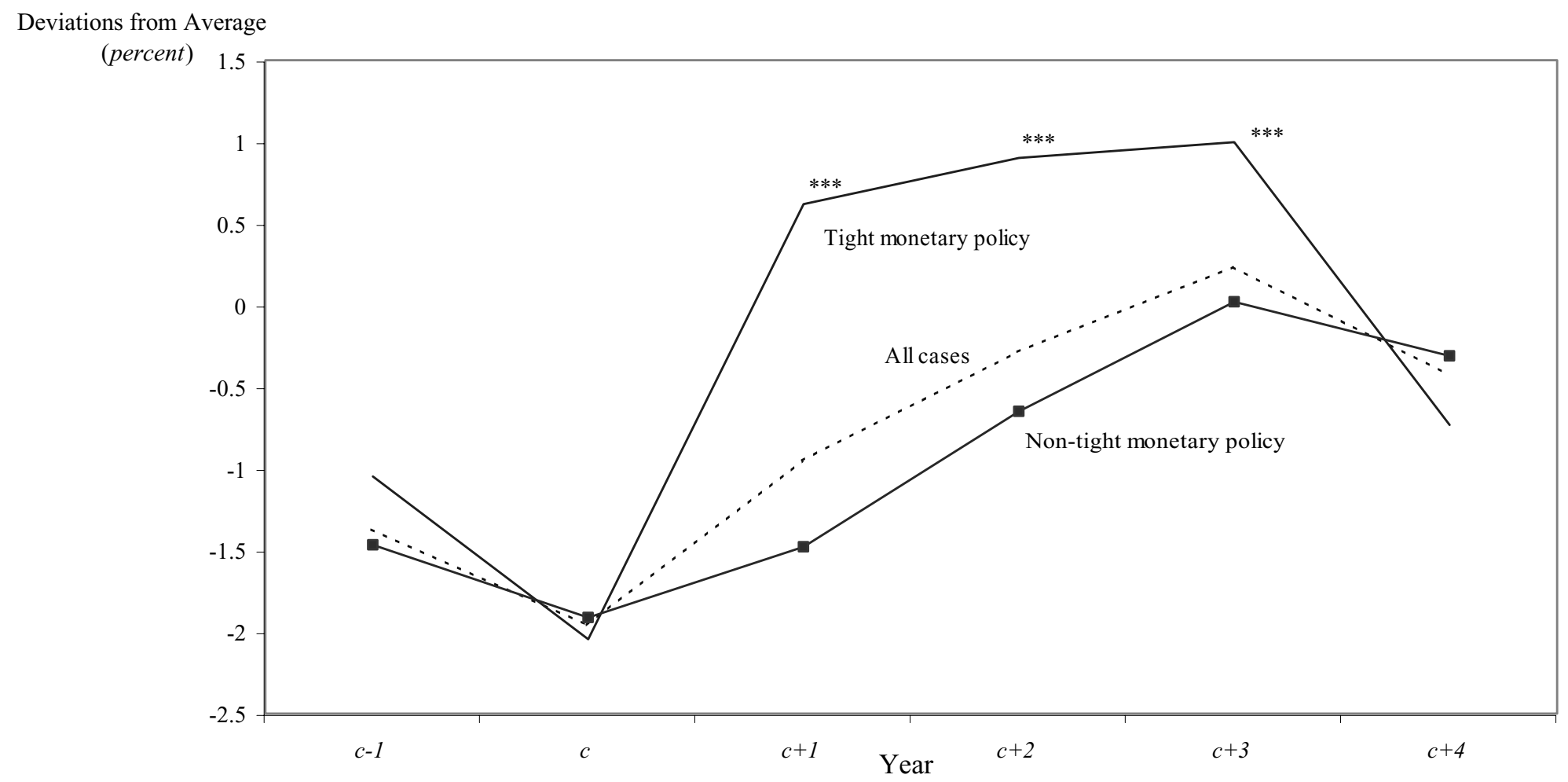

Sources: IMF, International Financial Statistics database; and authors' calculations.

Note: The symbols $* * *, * *$, and $*$ denote statistically significant $t$-ratios (for differences in values for tight and non-tight monetary policy) at the 1,5 , and 10 percent levels, respectively. 
debt servicing is relatively higher for the tight monetary cases. ${ }^{13}$ Finally, Figure 9 shows the behavior of the growth rate of output. Here we find that during the undervaluation periods, it is lower than the average. Somewhat surprisingly, we find that the recovery of output is sharper in tight monetary cases than in non-tight cases. This result may be attributed to the fact that tight monetary policies are usually associated with more successful reversals and, therefore, with economies recovering with relatively less inflation and more nominal appreciations.

\section{Panel Data Estimation and Limitations}

The analysis has so far treated each currency crisis as a single event and has not analyzed the time-series relationship between interest rates and exchange rates in the aftermath of currency crises. To fill this gap, we further analyze the effectiveness of monetary policy in correcting the undervaluation in RER estimating a fixed-effects model using monthly panel data. We consider undervaluations greater than 15 percent and, hence, consider 77 episodes of undervaluation for this exercise. The panel data consist of time-series observations for cases of undervaluation. Since the duration of undervaluation differed across cases, we estimated the model with an unbalanced panel.

We estimated the model by regressing the deviation of the real exchange rate from the equilibrium exchange rate, RER (which measures the extent of undervaluation), on real interest rates, controlling for the case-specific fixed effects. The model specification is given as

$$
y_{i t}=\alpha_{i}+\beta x_{i t}+u_{i t}
$$

where $y$ is the deviation of real exchange rate from equilibrium, subscript $i$ refers to the $i$ th case, and subscript $t$ to the time period. Notice that $t$ is different across cases. A constant term $\alpha$ is assumed to differ across cases. The real interest rate is denoted by $x$, and $u$ is the error term with mean zero and constant variance.

Table 6 contains the main results from this regression exercise. The coefficient of the real interest rate is found to be positive and significant at the 99 percent level of significance, which implies that high real interest rates help in correcting undervaluation.

In light of the recent debate on the effectiveness of monetary policy in the presence of a fragile banking sector, it would also be interesting to see how the latter affects the relationship between the RER and the interest rate. Hence we include a dummy variable for banking crisis in the estimation model and also interact it with the RER. The results are presented in the second and third columns of Table 6. Interestingly, the results show that when there is a banking crisis the RER is more undervalued, though not significantly so. Moreover, the use of an interest rate policy in such cases may not yield the desired effect. The coefficient on the interaction term is indeed negative, though significant only at 90 percent, which implies that when the economy is also experiencing a banking crisis, higher interest rates may result in more depreciation of the RER.

${ }^{13}$ We also examine the ratio of debt servicing to debt and find that it behaves similarly. 


\section{Table 6. Panel Data Regressions of Real Exchange Rate ${ }^{1}$}

$\begin{array}{lccc}\text { Sample } & \begin{array}{c}\text { Coefficient }^{2} \\ (t \text {-statistic })\end{array} & \begin{array}{c}\text { Coefficient }^{2} \\ (t \text {-statistic })\end{array} & \begin{array}{c}\text { Coefficient }^{2} \\ (t \text {-statistic })\end{array} \\ \text { Interest rate } & 0.0554 & 0.056 & 0.077 \\ & (3.19)^{* * *} & (3.25)^{* * *} & (4.99)^{* * *} \\ \text { Banking crisis } & & -0.893 & -0.576 \\ & (-1.42) & (-0.939) \\ \text { Interest rate and } & & -0.0498 \\ \text { banking crisis } & & (-1.814)^{*}\end{array}$

Source: Authors' calculations.

${ }^{1}$ Dependent variable is deviation of the real exchange rate from the equilibrium value, and the independent variable is the real interest rate.

$2^{* * *}$ denotes $t$-ratios statistically significant at the 99 percent level; ${ }^{* *}$ denotes significance at the 95 percent level; and * denotes significance at the 90 percent level.

The econometric analysis presented above, however, is subject to important caveats owing to the endogeneity and sample-selection issues. It may be argued that if the choice of monetary policy is endogenous to inflation and the real exchange rate, then our results on the effectiveness of monetary policy would be biased. For example, the government may have a reaction function whereby it increases interest rates if inflation picks up. This kind of behavior would, however, only give a downward bias to our results, since it implies that there would be more cases of high inflation (that is, more unsuccessful cases) associated with high interest rates. ${ }^{14}$

Second, it may be argued that the analysis suffers from the omitted-variables problem. It is possible that a third factor, for example loss of confidence among foreign investors, may increase both interest rates and exchange rates. Thus we may see high interest rates associated with more unsuccessful cases, but this need not imply causality between the two variables. Truly we cannot say anything about causality here, but as far as the direction of bias goes, the presence of such common factors would, if anything, provide a downward bias to our results.

Third, our analysis may also suffer from the sample-selection problem - that is, we tend to exclude the cases where tough governments (and, hence, tight monetary policy) are able to prevent crises. In this case, we should observe fewer cases of tight monetary policy and fewer successes in our sample. This, again, will bias the results encountered in the study. We do find, however, that about 30 percent of our cases have tight monetary policy and that these cases are relatively more successful.

Finally, tight monetary policy may be accompanied by a whole package of reforms. It would be difficult to disentangle the effects of these reforms and those of tight monetary policy in facilitating the reversal of exchange rate undervaluation.

${ }^{14}$ To address the endogeneity issues, we estimate a model using only cross-section data, with 77 episodes of undervaluation, and use a central bank independence index as an instrument. The main results, which are not reported here for the sake of brevity, remain unchanged. We would like to thank Aart Kraay for the data and suggestions. 


\section{Conclusion}

This study provides empirical evidence relating to the debate about the effectiveness of tight monetary policy in stabilizing exchange rates in the aftermath of currency crises. Although exogenous monetary policy variables are not available, at least not for a large set of countries, and true causality claims cannot be offered, the relationships encountered in this study provide food for thought.

The study finds that in a large set of undervaluations in the aftermath of currency crises, tight monetary policy substantially increases the probability of reversing undervaluation through nominal appreciation rather than through higher inflation. When the country is also experiencing a banking crisis, however, the results are not robust: depending on the specification, a tight monetary policy may reduce the probability of a reversal of currency undervaluation through currency appreciation.

The study also looks at the effects of tight monetary policy on inflation, the current account balance, and output growth. It finds that inflation declines more sharply in the cases with tight monetary policy. The current account improves after the implementation of tight monetary policy and remains stronger than in the nontight monetary policy cases. Interestingly, the study also finds that the recovery of output is steeper in the tight monetary policy cases than in non-tight monetary policy cases. This result may be attributed to the reforms undertaken along with tight monetary policy or simply to the restoration of investors' confidence brought about by the nominal appreciation of the currency.

\section{APPENDIXES}

\section{Countries in the Sample}

$\begin{array}{llll}\text { Argentina } & \text { Ethiopia } & \text { Kenya } & \text { Rwanda } \\ \text { Australia } & \text { Finland } & \text { Korea, Republic of } & \text { Senegal } \\ \text { Austria } & \text { France } & \text { Madagascar } & \text { Sierra Leone } \\ \text { Bahrain } & \text { Gabon } & \text { Malawi } & \text { Singapore } \\ \text { Bangladesh } & \text { Germany } & \text { Malaysia } & \text { South Africa } \\ \text { Belgium } & \text { Ghana } & \text { Mexico } & \text { Spain } \\ \text { Bolivia } & \text { Greece } & \text { Morocco } & \text { Sri Lanka } \\ \text { Brazil } & \text { Guatemala } & \text { Nepal } & \text { Sweden } \\ \text { Burkina Faso } & \text { Haiti } & \text { Netherlands } & \text { Switzerland } \\ \text { Burundi } & \text { Honduras } & \text { New Zealand } & \text { Thailand } \\ \text { Cameroon } & \text { Hong Kong SAR } & \text { Nigeria } & \text { Togo } \\ \text { Canada } & \text { Hungary } & \text { Norway } & \text { Trinidad and Tobago } \\ \text { Central African Republic } & \text { India } & \text { Pakistan } & \text { Tunisia } \\ \text { Chile } & \text { Indonesia } & \text { Papua New Guinea } & \text { Turkey } \\ \text { Colombia } & \text { Ireland } & \text { Paraguay } & \text { United Kingdom } \\ \text { Costa Rica } & \text { Israel } & \text { Peru } & \text { United States } \\ \text { Denmark } & \text { Italy } & \text { Philippines } & \text { Uruguay } \\ \text { Ecuador } & \text { Jamaica } & \text { Poland } & \text { Venezuela } \\ \text { Egypt } & \text { Japan } & \text { Portugal } & \text { Zambia } \\ \text { El Salvador } & \text { Jordan } & \text { Romania } & \text { Zimbabwe } \\ & & & \end{array}$




\section{Chi-Square Test Concerning Differences Among Proportions}

To test the null hypothesis $\theta_{1}=\theta_{2}$, if $x \mathrm{~s}$ are observed values of a set of independent random variables having joint binomial distributions with the respective parameters $n_{i}$ and $\theta_{i}$; and the $n$ s are sufficiently large, we can approximate the distribution of the independent random variables $z_{i}$ as

$$
z_{i}=\frac{x_{i}-n_{i} \theta_{i}}{\sqrt{n_{i} \theta\left(1-n_{i} \theta\right)}} \text { for } i=1,2, \ldots
$$

with standard normal distributions and

$$
\chi^{2}=\sum_{i=1}^{k} \frac{\left(x_{i}-n_{i} \hat{\theta}_{i}\right)^{2}}{n_{i} \hat{\theta}\left(1-n_{i} \hat{\theta}_{i}\right)} \text { where } \hat{\theta}=\frac{x_{i}+x_{2}}{n_{i}+n_{2}},
$$

as a value of a random variable having the chi-square distribution with $k-1$ degrees of freedom.

\section{BIBLIOGRAPHY}

Baig, Taimur, and Ilan Goldfajn, 1999, "Financial Market Contagion in the Asian Crisis," Staff Papers, International Monetary Fund, Vol. 46, No. 2, pp. 167-95.

+2002 , "Monetary Policy in the Aftermath of Currency Crises: The Case of Asia," Review of International Economics, Vol. 10, No. 1, pp. 92-112.

Caprio, Gerard J., and Daniela Klingebiel, 1996, "Bank Insolvency: Bad Luck, Bad Policy or Bad Banking?" paper presented at the Annual World Bank Conference on Development Economics, Washington. Available on the web at http://www.worldbank.org/research/interest/ prr_stuff/working_papers.abcde96.pdf.

Demirgüç-Kunt, Aslí, and Enrica Detragiache, 1998, "The Determinants of Banking Crises in

Developing and Developed Countries," Staff Papers, International Monetary Fund, Vol. 45, No. 1, pp. 81-109.

Dornbusch, Rudiger, 1976, "Expectations and Exchange Rate Dynamics," Journal of Political Economy, Vol. 84 (December), pp. 1161-76.

Drazen, Allan, and Paul R. Masson, 1994, "Credibility of Policies versus Credibility of Policy Makers," Quarterly Journal of Economics, Vol. 109 (August), pp. 735-54.

Eichengreen, Barry, Andrew K. Rose, and Charles Wyplosz, 1994, "Speculative Attacks on Pegged Exchange Rates: An Empirical Exploration with Special Reference to the European Monetary System," NBER Working Paper No. 4898 (Cambridge, Massachusetts: National Bureau of Economic Research).

Flood, Robert. P., and Olivier Jeanne, 2000, “An Interest Rate Defense of a Fixed Exchange Rate?” IMF Working Paper 00/159 (Washington: International Monetary Fund).

Furman, Jason, and Joseph E. Stiglitz, 1998, "Economic Crises: Evidence and Insights from East Asia," Brookings Papers on Economic Activity: 2, Brookings Institution, pp. 1-135.

Ghosh, Atish, and Steven Phillips, 1998, "Interest Rates, Stock Market Prices and Exchange Rates in East Asia" (unpublished; Washington: International Monetary Fund).

Goldfajn, Ilan, and Rodrigo O. Valdés, 1998, "The Aftermath of Appreciations," Quarterly Journal of Economics, Vol. 114 (February), pp. 229-62.

Kaminsky, Graciela L., and Carmen M. Reinhart, 1999 "The Twin Crises: The Causes of Banking and Balance of Payments Problems," American Economic Review, Vol. 89 (June), pp. 473-500. 


\section{Ilan Goldfajn and Poonam Gupta}

Kaminsky, Graciela, and Sergio Schmukler, 1998, "The Relationship Between Interest Rates and Exchange Rates in Six Asian Countries" (unpublished; Washington: World Bank).

Kindleberger, Charles P., 1978, Manias, Panics and Crashes: A History of Financial Crises (New York: Basic Books).

Kraay, Aart, 1998, "Do High Interest Rates Defend Currencies During Speculative Attacks?" World Bank Policy Research Working Paper No. 2267 (Washington).

Krugman, Paul, 1998a, "What Happened to Asia?" Available on the web at http://web.mit.edu/krugman/www/DISINTER.html.

— 1998b, "Will Asia Bounce Back?" Available on the web at http://web.mit.edu/krugman/ www/suisse.html.

Lindgren, Carl-Johan, Gillian Garcia, and Matthew I. Saal, 1996, Bank Soundness and Macroeconomic Policy (Washington: International Monetary Fund).

Radelet, Steven, and Jeffrey D. Sachs, 1998, "The East Asian Financial Crisis: Diagnosis, Remedies, Prospects," Brookings Papers on Economic Activity: 1, Brookings Institution, pp. 1-90.

Stiglitz, Joseph E., 1998, "Knowledge for Development: Economic Science, Economic Policy and Economic Advice," paper presented at the Annual World Bank Conference on Development Economics, Washington, April 20. Available on the web at http://www.worldbank.org/html/extdr/js-abcde98/js_abcde98.htm. 